\title{
Oxidative DNA damage triggers ProNGF-Mediated apoptosis in the striatum of 6-OHDA-treated rats
}

\author{
Tao Wang ${ }^{1}$, Pingping Zuo ${ }^{2}$, Piu Chan ${ }^{1^{*}}$ \\ From 2011 International Conference on Molecular Neurodegeneration \\ Shanghai, China. 22-24 September 2011
}

\section{Background}

Oxidative DNA damage generated by 6-hydroxydopamine (6-OHDA) may initiate a programmed cell death cascade called apoptosis and plays an important role in the pathogenesis of Parkinson's disease (PD). ProNGF, a precursor of nerve growth factor (NGF), is found to be involved in neuronal apoptosis of neurodegenerative diseases such as PD. Therefore, we have tested the presumption that proNGF-mediated apoptosis might be initiated by oxidative DNA damage in 6-OHDA treated rats.

\section{Method}

Enzymatic assay, histochemistry, TUNEL and Western blot were used to investigate profiles of pro-NGF mediated apoptosis after oxidative DNA damage in a unilateral 6-OHDA treated rat model of PD.

\section{Result}

A signaling cascade of proNGF-mediated apoptosis definitely occurred in striatum of 6-OHDA lesioned rat under a circumstance of oxidative DNA damage. We confirmed the following changes: 1) activities of antioxidant defense system and levels of malondialdehyde (MDA), 2) MTH1 levels and 8-oxo-2'-deoxyguanosine (8-oxo-dG) accumulation, 3) loss of the TH-positive fiber and dopamine neurons in nigrosriatal system, 4) appearance of apoptotic body and neuronal apoptosis in striatum, 5) expression of proNGF and downstream coreceptor of sportily and p75NTR, 6) activation status of c-Jun N-terminal kinase (JNK) and its target p53, 7) activation status of the intrinsic apoptotic pathway including cytochrome $c$, caspase 9 and caspase 3,8) phosphorylation levels of $\mathrm{Bad}$ and ratio of $\mathrm{Bax} / \mathrm{Bcl}-2$.

${ }^{1}$ Department of Neurobiology, Beijing Institute of Geriatrics, Xuanwu Hospital of Capital Medical University, Beijing 100053, China

Full list of author information is available at the end of the article

\section{Conclusion}

These results support that after exposure to the stress stimuli such as oxidative DNA damage induced by 6OHDA, the destiny of neuronal cells in striatum finally went to apoptosis mediated by proNGF-mediated signaling and it suggests that these profiles might provide some clues for the possible molecular basis of PD etiology.

\section{Author details}

'Department of Neurobiology, Beijing Institute of Geriatrics, Xuanwu Hospital of Capital Medical University, Beijing 100053, China. ${ }^{2}$ Department of Pharmacology, Institute of Basic Medical Sciences, Peking Union Medical College \& Chinese Academy of Medical Sciences, Beijing, China.

Published: 7 February 2012

doi:10.1186/1750-1326-7-S1-S20

Cite this article as: Wang et al:: Oxidative DNA damage triggers

ProNGF-Mediated apoptosis in the striatum of 6-OHDA-treated rats. Molecular Neurodegeneration 2012 7(Suppl 1):S20.

Submit your next manuscript to BioMed Central and take full advantage of:

- Convenient online submission

- Thorough peer review

- No space constraints or color figure charges

- Immediate publication on acceptance

- Inclusion in PubMed, CAS, Scopus and Google Scholar

- Research which is freely available for redistribution (c) 2012 Wang et al; licensee BioMed Central Ltd. This is an Open Access article distributed under the terms of the Creative Commons Attribution License (http://creativecommons.org/licenses/by/2.0), which permits unrestricted use, distribution, and reproduction in any medium, provided the original work is properly cited. 